\title{
ANALISIS SPASIAL KEJADIAN PENYAKIT LEPTOSPIROSIS DI KABUPATEN SLEMAN PROPINSI DAERAH ISTIMEWA YOGYAKARTA TAHUN 2011
}

\author{
Ferry Febrian, Solikhah \\ Fakultas Kesehatan Masyarakat, Universitas Ahmad Dahlan, Yogyakarta
}

\begin{abstract}
Background: Leptospirosis is an acute infectious disease that can infect humans and animals (zoonoses). The cause of the disease is Leptospira. Leptospirosis is spread all over the world, including Indonesia. Yogyakarta is one of are endemis of leptospirosis. Spatial analysis is an analysis and description of the geography of disease data with regard to population distribution, the distribution of environmental risk factors, ecosystem, social and economic, as well as analysis of relationships between variables. Objective to analyze the incidence of the disease leptospirosis spatially and risk factors Sleman District of Yogyakarta Province in 2011.

Methods: The study was descriptive research and used map leptospirosis disease in Sleman District of Yogyakarta Province in 2011. The data has got Health Office of Sleman District.

Results: Patients with leptospirosis was highest in Moyodan. Spatial analysis showed most leptospirosis occurs in locations with pet ownership $(59,1 \%)$, the presence of rat $(85,2 \%)$, vegetation (100\%), and occurred in the location of the trenches / ditches around the house $(47,5 \%)$.

Conclusion: It should be done to inform the public about the disease leptospirosis, and Public Health Service Sleman need to develop early warning systems so that more optimal disease eradication.
\end{abstract}

Keywords : zoonoses, leptospirosis, spatial analysis, risk factors.

\section{PENDAHULUAN}

Leptospirosis merupakan masalah kesehatan masyarakat di seluruh dunia, khususnya negara-negara yang beriklim tropis dan subtropis yang memiliki curah hujan tinggi. ${ }^{1}$ Leptospirosis adalah salah satu penyakit infeksi yang terabaikan atau Neglected Infectious Diseases (NIDs) yaitu penyakit infeksi yang endemis pada masyarakat miskin atau populasi petani dan pekerja yang berhubungan dengan air dan tanah di negera berkembang. Leptospirosis merupakan zoonosis yang paling luas tersebar di seluruh dunia, kecuali daerah kutub. Leptospirosis adalah penyakit menular yang disebabkam oleh bakteri Leptospira yang pathogen. ${ }^{2}$

Kejadian leptospirosis untuk negara subtropis adalah berkisar antara 0,1-1 kejadian tiap 100.000 penduduk per tahun, sedangkan di negara tropis berkisar antara 10-100 kejadian tiap 100.000 penduduk per tahun. ${ }^{1}$ Tingginya angka prevalensi leptospirosis di daerah yang memiliki iklim tropis dan subtropis, dapat dihubungkan dengan kondisi lingkungan yang kurang baik sehingga memungkinkan lingkungan tersebut menjadi tempat yang baik atau cocok untuk hidup dan berkembangbiaknya bakteri Leptospira.

International Leptospirosis Society menyatakan bahwa Indonesia merupakan salah satu negara tropis dengan kasus kematian leptospirosis relatif tinggi, yaitu berkisar antara 2,5\%-16,45\% atau rata-rata $7,1 \%$ dan termasuk peringkat tiga di dunia. Angka kematian ini dapat lebih tinggi hingga mencapai 56\% pada kasus yang telah berusia lebih dari 50 tahun, jika terlambat mendapatkan terapi. $^{2}$ 
Penyakit secara epidemiologik dipengaruhi oleh 3 faktor pokok yaitu faktor agent penyakit yang berkaitan dengan penyebab termasuk jumlah, virulensi, patogenitas bakteri Leptospira, faktor kedua yang berkaitan dengan faktor host (penjamu) termasuk di dalamnya keadaan kebersihan perorangan, keadaan gizi, usia, taraf pendidikan, dan faktor ketiga yaitu lingkungan. Pada kejadian leptospirosis faktor risiko lingkungan yang sangat berpengaruh seperti adanya genangan air dan sanitasi yang buruk. ${ }^{3}$ Penyakit leptospirosis dapat terjadi sebagai risiko pekerjaan (occupational hazard) yang umumnya menyerang petani, pekerja tambang, dokter hewan, peternak, peternak sapi perah, pekerja yang bekerja di pemotongan hewan, nelayan, dan tentara. ${ }^{4}$

Berdasarkan profil kesehatan Propinsi Daerah Istimewa Yogyakarta tahun 2011 menyebutkan jumlah kematian kasus atau Case Fatality Rate leptospirosis adalah 6,87\%, dengan rincian kejadian tertinggi penyakit leptospirosis di Kota Yogyakarta (CFR=17,95\%), Kabupaten Bantul (CFR=7,79\%), Kabupaten Kulon Progo (CFR=5,78\%), Kabupaten Gunung Kidul (CFR=5,56\%), dan kejadian penyakit leptospirosis terendah di Kabupaten Sleman (CFR=4,41\%). Kabupaten Sleman angka CFR terendah di Propinsi Daerah Istimewa Yogyakarta, namun masih diatas angka CFR secara nasional yaitu sebesar 2,5-16,45\%. ${ }^{5}$

Kabupaten Sleman merupakan daerah endemis penyakit leptospirosis dengan kecenderungan terjadi peningkatan. Case fatality rate (CFR) kasus leptospirosis di Kabupaten Sleman tahun 2007 sebesar 12,5\% (8 kasus dan 1 meninggal), tahun 2008 sebesar 6,06\% (33 kasus dan 2 meninggal), tahun 2009 sebesar $6,25 \%$ (80 kasus dan 5 meninggal), tahun 2010 sebesar 4,69\% (64 kasus dan 3 meninggal), dan pada tahun 2011 sebesar 4,41\% (68 kasus dan 3 meninggal). Rata-rata angka CFR dari tahun 2007 sampai 2011 di Kabupaten Sleman yaitu $6,78 \%$. Angka CFR Kabupaten Sleman tersebut diatas angka CFR secara nasional yaitu $2,55-16,45 \%{ }^{6}$

Upaya penanggulangan penderita leptospirosis di Kabupaten Sleman saat ini hanya terbatas pada penyuluhan dan pengobatan penderita, sedangkan pencarian penderita, cara pencegahan, penularan leptospirosis dari tikus ke manusia, serta pengendalian reservoir yang tepat dan efisien agar tidak menularkan leptospirosis kepada masyarakat yang lebih luas, belum pernah dilaksanakan secara terpadu. Sebagian besar masyarakat belum mengetahui penyebab, faktor risiko dan cara pencegahan serta penganggulangan leptospirosis, hal tersebut disebabkan oleh terbatasnya informasi faktor-faktor yang berasosiasi dengan kejadian leptospirosis. ${ }^{2}$

Geographical Information System (GIS) adalah sistem pengelolaan data berbasis komputer yang digunakan untuk memanipulasi data bereferensi geografi. Pemanfaatan Sistem Informasi Geografis (SIG) disajikan dalam bentuk spasial membantu dalam menampilkan dan membandingkan distribusi hubungan letak objek, dalam hal ini mempermudah memberikan gambaran letak atau lokasi kesehatan, penyebaran penyakit, kondisi kesehatan lainnya. Visualisasi dalam bentuk data spasial berpotensi secra signifikan untuk memperbaiki perencanaan dan pengambilan keputusan.

Analisis spasial merupakan salah satu metodologi manajemen penyakit berbasis wilayah, merupakan suatu analisis dan uraian tentang data penyakit secara geografi berkenaan dengan distribusi kependudukan, persebaran faktor risiko lingkungan, ekosistem, sosial ekonomi, serta analisis hubungan antarvariabel tersebut. Pemanfaatan analisis spasial pada bidang kesehatan dilakukan agar diketahui cara pandang tentang hubungan kesehatan dan lingkungan serta menganalisis upaya untuk penanganannya. ${ }^{7}$ 
Berdasarkan latar belakang diatas maka peneliti bermaksud melakukan penelitian yang berjudul Analisis Spasial Kejadian Penyakit Leptospirosis di Kabupaten Sleman Propinsi Daerah Istimewa Yogyakarta tahun 2011.

\section{METODE PENELITIAN}

Jenis penelitian ini adalah penelitian deskriptif kuantitatif. Penelitian ini digunakan untuk menggambarkan dan memetakan kejadian penyakit leptospirosis di Kabupaten Sleman Propinsi Daerah Istimewa Yogyakarta tahun 2011. Penelitian ini dilaksanakan pada bulan Juli-Agustus tahun 2012. Populasi dalam penelitian ini adalah seluruh penderita leptospirosis yang terdata di wilayah kerja Dinas Kesehatan Kabupaten Sleman tahun 2011. Cara pengambilan obyek menggunakan totality sampling. Jumlah penderita penyakit leptospirosis di Kabupaten Sleman dari Januari sampai Desember tahun 2011 yaitu sebanyak 61 penderita sembuh.

Sumber data adalah data primer dan data sekunder. Data primer berasal dari hasil wawancara, observasi dan pengukuran langsung dilapangan tentang letak geografis penderita leptospirosis dan factor risikonya. Data sekunder dari Dinas Kesehatan Kabupaten Sleman. Alat pengumpulan data adalah kuesioner, checklist, GPS (Global Positioning System) merk Garmin e-trex. Pengolahan dan analisis data dengan program SPSS for windows versi 16.00 dan Software pengolahan analisis spasial dengan ArcGIS 9,3.

\section{HASIL PENELITIAN DAN PEMBAHASAN}

\section{A. Hasil Penelitian}

Faktor risiko lingkungan kejadian penyakit leptospirosis yang diteliti adalah kepemilikan hewan peliharaan, keberadaan tikus, keberadaan vegetasi, dan keberadaan parit/selokan.

1) Kepemilikan hewan peliharaan

Berdasarkan data hasil penelitian menunjukkan bahwa jumlah responden yang memiliki hewan peliharaan adalah sebanyak 45 responden $(73,8 \%)$ dan jumlah responden yang tidak memiliki hewan peliharaan adalah sebanyak 16 responden (26,2\%). Perbandingan ini menunjukkan bahwa responden dalam penelitian ini adalah mayoritas memiliki hewan peliharaan, yang dapat dilihat pada tabel berikut;

Tabel 1. Distribusi Frekuensi Responden Berdasarkan Kepemilikan Hewan Peliharaan di Wilayah Kabupaten Sleman Propinsi Daerah Istimewa Yogyakarta Tahun 2011.

\begin{tabular}{ccc}
\hline $\begin{array}{c}\text { Kepemilikan Hewan } \\
\text { Peliharaan }\end{array}$ & $\begin{array}{c}\text { Jumlah } \\
\text { Responden }\end{array}$ & Presentase (\%) \\
\hline Memiliki & 45 & 73,8 \\
Tidak memiliki & 16 & 26,2 \\
Jumlah & 61 & 100 \\
\hline
\end{tabular}

2) Keberadaan Tikus

Berdasarkan data hasil penelitian menunjukkan bahwa jumlah responden yang terdapat keberadaan tikus adalah sebanyak 54 responden $(88,5 \%)$ dan jumlah responden yang tidak terdapat keberadaan tikus adalah sebanyak 7 responden (11,5\%). Perbandingan ini menunjukkan bahwa 
mayoritas terdapat keberadaan tikus disekitar rumah responden, yang dapat dilihat pada tabel berikut;

Tabel 2. Distribusi Frekuensi Responden Berdasarkan Keberadaan Tikus di Wilayah Kabupaten Sleman Propinsi Daerah Istimewa Yogyakarta Tahun 2011.

\begin{tabular}{ccc}
\hline Keberadaan Tikus & Jumlah Responden & Presentase $(\%)$ \\
\hline Ada & 54 & 88,5 \\
Tidak & 7 & 11,5 \\
Jumlah & 61 & 100 \\
\hline
\end{tabular}

3) Keberadaan Vegetasi

Berdasarkan data hasil penelitian menunjukkan bahwa jumlah responden penderita leptospirosis yang terdapat keberadaan parit/selokan disekitar rumah adalah sebanyak 61 responden (100\%) dan jumlah responden yang memiliki sedikit keberadaan vegetasi adalah sebanyak 0 responden $(0 \%)$. Perbandingan ini menunjukkan bahwa dalam penelitian ini seluruh responden memiliki banyak vegetasi disekitar rumah, yang dapat dilihat pada tabel berikut;

Tabel 3. Distribusi Frekuensi Responden Berdasarkan Keberadaan Vegetasi di Wilayah Kabupaten Sleman Propinsi Daerah Istimewa Yogyakarta Tahun 2011.

\begin{tabular}{ccc}
\hline Keberadaan Vegetasi & $\begin{array}{c}\text { Jumlah } \\
\text { Responden }\end{array}$ & Presentase (\%) \\
\hline Banyak & 61 & 100 \\
Sedikit & 0 & 0 \\
Jumlah & 61 & 100 \\
\hline
\end{tabular}

4) Keberadaan Parit/Selokan

Berdasarkan data hasil penelitian menunjukkan bahwa jumlah responden yang terdapat keberadaan parit/selokan disekitar rumah sebanyak 47 responden $(77,0 \%)$ dan jumlah responden yang tidak terdapat keberadaan parit/selokan disekitar rumah sebanyak 14 responden $(23,0 \%)$. Perbandingan ini menunjukkan bahwa responden dalam penelitian ini adalah mayoritas terdapat keberadaan parit/selokan disekitar rumah, yang dapat dilihat pada tabel berikut;

Tabel 4. Distribusi Frekuensi Responden Berdasarkan keberadaan parit atau selokan di Wilayah Kabupaten Sleman Propinsi Daerah Istimewa Yogyakarta Tahun 2011.

\begin{tabular}{ccc}
\hline Keberadaan Parit/Selokan & $\begin{array}{c}\text { Jumlah } \\
\text { Responden }\end{array}$ & Presentase (\%) \\
\hline Ada & 47 & 77,0 \\
Tidak & 14 & 23,0 \\
Jumlah & 61 & 100 \\
\hline
\end{tabular}

\section{B. Pembahasan}

Berdasarkan data sekunder yang diperoleh dari Dinas Kesehatan Kabupaten Sleman Propinsi Daerah Istimewa Yogyakarta bahwa tingkat kejadian penyakit leptospirosis pada periode Januari-Desember Tahun 2011 adalah sebanyak 61 kasus sembuh. Jumlah penderita penyakit leptospirosis 
tertinggi ditemukan di wilayah Kecamatan Moyudan yaitu 33 kasus, dan penderita penyakit terendah ditemukan di Kecamatan Tempel dengan jumlah 1 kasus, Kecamatan Berbah dengan jumlah 1 kasus, dan Kecamatan Seyegan dengan jumlah 1 kasus.

Analisis Spasial yang dilakukan terhadap faktor risiko lingkungan kepemilikan hewan peliharaan dengan kejadian leptospirosis menunjukkan bahwa 36 kasus $(59,1 \%)$ kejadian leptospirosis terjadi pada lokasi dengan kepemilikan hewan peliharaan seperti anjing, sapi, babi, kambing, dan kucing, dan atau salah satunya, sedangkan 25 kasus $(40,9 \%)$ kejadian leptospirosis terjadi pada lokasi dengan tidak memiliki hewan peliharaan. Hal ini berarti sebagian besar kejadian leptospirosis terjadi di lokasi dengan kepemilikan hewan peliharaan $(59,1 \%)$.

Di sebagian besar Negara tropis termasuk Negara berkembang kemungkinan paparan leptospirosis tersebar pada manusia karena terinfeksi dari binatang ternak, binatang rumah maupun binatang liar. Keberadaan leptospirosis pada ternak juga merupakan hal yang harus diwaspadai oleh peternak dan orang yang berhubungan dengan produk dari ternak. ${ }^{8}$

Analisis Spasial yang terhadap faktor risiko lingkungan keberadaan tikus dengan kejadian penyakit leptospirosis menunjukkan bahwa 52 kasus $(85,2 \%)$ kejadian leptospirosis terjadi pada kelurahan yang terdapat keberadaan tikus di rumah responden. Sedangkan $9(14,8 \%)$ kejadian leptospirosis terjadi pada kelurahan yang tidak terdapat keberadaan tikus di rumah responden. Hal ini berarti sebagian besar kejadian leptospirosis terjadi di lokasi dengan terdapat keberadaan tikus disekitar rumah.

Tikus dikategorikan sebagai reservoir bakteri Leptospira yang sangat potensial, karena $>50 \%$ tikus dapat mengeluarkan bakteri Leptospira secara terus menerus (masif) melalui urin selalam hidupnya, tanpa menunjukkan gejala sakit. Keberadaan tikus disekitar rumah penderita, dapat mempermudah terkontaminasi dengan bakteri leptospirosis. ${ }^{2}$

Analisis spasial yang dilakukan terhadap faktor resiko lingkungan keberadaan vegetasi dengan kejadian leptospirosis menunjukkan bahwa 61 kasus (100\%) kejadian leptospirosis terjadi pada lokasi dengan 3 jenis vegetasi atau lebih, hal ini berarti kejadian leptospirosis terjadi di lokasi dengan 3 jenis vegetasi atau lebih yang merupakan lokasi potensial menjadi habitat tikus sebagai reservoir bakteri Leptospira.

Vegetasi adalah kumpulan spesies tumbuh-tumbuhan yang memiliki kontribusi terhadap keberadaan tikus. Keanekaragaman dan kepadatan vegetasi di daerah endemik leptospirosis, berpengaruh terhadap ketersediaan sumber pakan dan tempat berlindung bagi tikus. Ketersediaan sumber pakan di suatu area sepanjang tahun menentukan perkembangbiakan dan kelangsungan hidup tikus, sedangkan kepadatan vegetasi di suatu area memberi perlindungan bagi tikus terhadap gangguan musuh alami atau predator. $^{2}$

Analisis spasial yang dilakukan terhadap faktor risiko lingkungan keberadaan parit/selokan menunjukkan bahwa 29 kasus $(47,5 \%)$ kejadian leptospirosis terjadi pada kelurahan dengan selokan di sekitar rumah yang berpotensi di lewati tikus, aliranya tidak lancar, menggenang, meluap saat hujan atau terdapat salah satu diantaranya, dan 32 kasus $(52,5 \%)$ kejadian leptospirosis terjadi pada kelurahan dengan tidak selokan di sekitar rumah yang berpotensi di lewati tikus, aliranya tidak lancar, menggenang, meluap saat hujan atau terdapat salah satu diantaranya. Secara visual perbedaan tidak terlalu besar antara kejadian leptospirosis yang terjadi di lokasi dengan terdapat keberadaan parit/selokan dengan lokasi leptospirosis yang tidak terdapat 
keberadaan parit/selokan. Perbandingan yang kecil menunjukan bahwa keberadaan parit/selokan disekitar rumah responden bukan merupakan salah satu faktor risiko leptospirosis tetapi disebabkan oleh faktor-faktor lain. Proses penularan leptospirosis melalui jalur selokan intinya pada saat air selokan yang diduga telah terkontaminasi urin tikus atau hewan piaraan lain yang terinfeksi bakteri Leptospira dan responden kontak dengan air selokan tersebut.

\section{SIMPULAN DAN SARAN}

A. Simpulan

Berdasarkan analisa hasil penelitian dan pembahasan pada penelitian ini maka dapat disimpulkan bahwa:

1) Kejadian leptospirosis tersebar merata hampir pada setiap kecamatan di Kabupaten Sleman tahun 2011, kejadian kasus leptospirosis tertinggi terjadi di Kecamatan Moyudan.

2) Analisis spasial terhadap faktor risiko lingkungan menunjukan sebagian besar kejadian leptospirosis terjadi di lokasi dengan kepemilikan hewan peliharaan, sebagian besar kejadian leptospirosis terjadi di lokasi dengan terdapat keberadaan tikus di sekitar rumah, leptospirosis terjadi di lokasi dengan tiga jenis vegetasi atau lebih, sementara itu kejadian leptospirosis belum terbukti terjadi di lokasi yang terdapat keberadaan parit/selokan.

\section{B. Saran}

1) Perlu dilakukan penyebaran informasi kepada masyarakat tentang penyakit leptospirosis, pentingnya memelihara personal hygiene, menjaga kebersihan lingkungan dan sanitasi untuk menghindari masyarakat dari penyakit leptospirosis.

2) Melakukan pengendalian faktor risiko lingkungan seperti kepemilikan hewan peliharaan, keberadaan tikus, keberadaan vegetasi, dan keberadaan parit/selokan yang diduga faktor penyebab tingginya kejadian penyakit leptospirosis.

3) Perlu dilakukan penelitian yang lebih lanjut mengenai gambaran dan faktor risiko kejadian penyakit leptosprirosis di Propinsi Daerah Istimewa Yogyakarta khususnya Kabupaten Sleman, mengingat masih banyak faktor risiko yang mempengaruhi leptospirosis yang belum diteliti dalam penelitian ini seperti penggunaan alat pelindung diri (APD) dan pengukuran kembali faktor risiko lingkungan keberadaan parit/selokan yang belum terbukti berpengaruh terhadap kejadian leptospirosis.

\section{DAFTAR PUSTAKA}

1. WHO, Human Leptospirosis : Guidance for Diagnosis, Surveillance and Control, Geneva. Hal. iii, iv, v, 2003.

2. Rusmini, Bahaya Leptospirosis (Penyakit kencing tikus) \& Cara Pencegahannya, Gosyen Publishing, Yogyakarta. Hal. 2, 3, 4, 14, 15, 59-85, 2011.

3. Rejeki, DSS., Faktor Risiko Lingkungan Yang Berpengaruh Terhadap Kejadian Leptospirosis Berat (Studi Kasus di Rumah Sakit Dr. Kariadi Semarang), Tesis, Program Studi Epidemiologi Universitas Diponogoro, Semarang. Hal. 78, 102-106, 109, 114, 2005.

4. Chin, J., Manual Pemberantasan Penyakit Menular. Edisi 17 Editor penterjemah : I Nyoman Kandun. Hal. 308, 309, 310, 311, 2000.

5. Dinas Kesehatan Propinsi Daerah Istimewa Yogyakarta, Profil Kesehatan Propinsi D.I Yogyakarta Tahun 2011, Yogyakarta, 2011. 
6. Dinas Kesehatan Kabupaten Sleman, Profil Kesehatan Kabupaten Sleman Tahun 2011, Sleman, 2011.

7. Achmadi, UF., Manajemen Penyakit Berbasis Wilayah, Penerbit Universitas Indonesia, Jakarta. Hal. 23, 24, 70, 71, 73, 74, 75, 80, 256-268, 2010.

8. Ningsih, R., Faktor Risiko Lingkungan Terhadap Kejadian Leptospirosis di Jawa Tengah (Studi Kasus di Kota Semarang, Demak dan Pati), Tesis, Program Pasca Sarjana Universitas Diponegoro, Semarang. Hal. 55, 56, 57, 62, 2009. 
